Knud Jeppesen

\title{
Problemer ved at oversætte Bibelen til dansk på ny
}

\begin{abstract}
In November 1989 the last issues of a trial translation to a forthcoming authorized Danish Bible version were released. The author, one of the editors of the translation, describes some of the problems connected to translating a text which already has a history in Danish language and literature and at the same time is dear to many people. A short introduction to the history of Bible translation in Denmark is given. The transmission of the text and the relation to the classic versions are touched upon, and finally some examples of changes from older translations to the new are discussed.
\end{abstract}

Den 15. nov. 1989 fejrede Det danske Bibelselskab, at et arbejde, som havde strakt sig over en længere årrække, var nået til en foreløbig afslutning. Siden midten af 70'erne har et udvalg arbejdet på at fremstille en ny dansk oversættelse af Det gamle Testamentes (GT) hebraiske grundtekst, og siden midten af 80'erne har et andet udvalg arbejdet på en tilsvarende nyoversættelse af Det ny Testamente (NT) fra græsk til dansk med henblik på at fremstille en ny autoriseret bibeloversættelse.

At dette ikke alene er en kirkelig begivenhed, men noget, der også har almindelig folkelig og kulturhistorisk interesse, kan man aflæse af den presseomtale nyoversættelserne har fået. Men netop den store interesse, der omgiver nyoversættelsen af et skrift som Bibelen, er en af de faktorer, der er med til at gøre det umuligt at oversætte "i fred". Man kan ikke bare sætte sig hen med sin tekst og sine grammatiske og leksikalske hjælpemidler og bruge sine oversættelsesteorier og metoder til at oversætte, sådan som man nu synes, det vil lyde bedst. Der er en vægt af tradition, som man må tage hensyn til. Man kan følge den eller lade være, men man kan i hvert tilfælde ikke negligere den. Bliver man stående ved det traditionelle sprog, kan man med rette sætte spørgsmålstegn ved, om en nyoversættelse overhovedet er nødvendig; men vælges derimod en ny og utraditionel sprogtone, føles det, som om oversætterne vil tage Bibelen fra ikke alene "kirkefolket", men fra hele det danske folk.

På de følgende sider vil jeg gøre rede for nogle af de problemer, vi som bibeloversættere har stået overfor. De teoretiske overvejelser, der gik forud for selve oversættelsesarbejdet, og som naturligvis er blevet justeret undervejs, vil skinne igennem undervejs og kan iøvrigt findes $i$ 
forordene til de forskellige bind af prøveroversættelsen (PO; se nedenfor).

Hvis jeg begyndte med en større teoretisk redegørelse, ville det give et forkert indtryk af oversættelsens forløb. Jeg har derfor valgt at begynde et andet sted for at understrege, at for oversættere, og specielt for bibeloversættere, kan der være hensyn, som gør, at man må gå på kompromis med oversættelsesteorierne.

Til hjælp for bibeloversættere er der på internationalt plan udgivet en lang række håndbøger og monografier, hvor man både finder teoretiske overvejelser og konkrete forslag til oversættelser. Man kan orientere sig om omfanget heraf ved at se i tidsskriftet The Bibletranslator, udgivet af The United Bible Societies; på indersiden af omslaget finder man en liste over tilgængelige hjælpemidler.

Danske oversættere har desuden kunnet øse af grundige overvejelser, gjort i Sverige i forbindelse med et bibeloversættelsesprojekt. Dér betragtes bibeloversættelse som en statslig opgave, d.v.s at Utbildningsdepartementet nedsatte kommissioner, der først skulle afgive betænkninger om oversættelsernes teori og praksis. Disse betænkninger er offentliggjort i serien af Statens offentliga utredningar med numrene 1968:65 (Nyöversättning af Nya testamentet. Behov och principper) og 1974:33 (Att översätta Gamla testamentet).

Sådanne "utredningar" er naturligvis af stor hjælp, men jeg tror, jeg kan tale for alle oversætterne, når jeg siger, at vi er glade for, at vi ikke, før vi gik i gang med selve oversættelsen, nedfældede vore principper i samme omfang som svenskerne. Det har stillet os friere $\mathrm{i}$ forhold til en række beslutninger, som vi har skullet tage i løbet af de år, der er gået med oversættelsen.

Lad mig i stedet for oversættelsesteoretiske udredninger som en slags introduktion give nogle stikord til belysning af den bagvedliggende problematik:

Bibelen er en oversat bog, men føles som en integreret del af dansk litteratur og har haft stor betydning for udviklingen af det danske sprog.

Bibelen er en antik tekst, der stammer fra et sted, der er langt fra dagens Danmark i tid og rum, men den kirke, der først og fremmest skal bruge oversættelsen, har den opfattelse, at Bibelen rummer et samtidigt og relevant budskab til dagens danskere.

Bibelen er overleveret som skriftlig litteratur, selv om der for store deles vedkommende ligger en mundtlig forkyndelse bag, og oversættelsen skal gerne være af en sådan karakter, at tekstens implicite budskab kan fanges, ikke alene når man læser teksten for sig selv og kan vende tilbage til vanskelige passager, men også når man hører teksten læst op. 
Jeg skal på de følgende sider prøve at belyse disse spændinger, men det vil ske indirekte. Jeg starter i den danske bibeloversættelses historie og fortsætter med nogle bemærkninger om forholdet mellem det traditionelle kirkelige sprog og "folkesproget" — hvis man overhovedet tør tale om noget sådant. I sidste del vil jeg gå over til at sige noget om de praktiske forhold omkring oversættelsen, hvordan vi har båret os ad, hvilket tekstgrundlag vi har arbejdet med for så til slut at give nogle eksempler på problemer ved at oversætte fra antik hebraisk og græsk til dansk; da undertegnede har sine erfaringer fra oversættelsen af hebraisk, vil eksemplerne især være hentet fra den gammeltestamentlige del af oversættelsesarbejdet.

\section{Træk af dansk bibeloversættelseshistorie.}

I 15.-16. årh. finder man dels et ønske om at komme bag om den latinske bibeltradition til grundteksten - og det hænger selvfølgelig sammen med den almene interesse $\mathrm{i}$ at vende tilbage til kilderne — dels et $\emptyset$ nske om at få Bibelen gjort tilgængelig på folkesprogene. Men det blev på den ene side bogtrykkerkunstens opfindelse og på den anden side reformationskirkerne, der for alvor kom til at sætte skub i den udvikling, at Bibelen blev oversat fra grundteksten og udbredt på nationalsprogene. De to store tysksprogede oversættelser fra reformationsårene blev i den sammenhæng afgørende; det drejer sig om den såkaldte Zürcherbibel fra 1531, der går tilbage til Zwinglis reformation i Zürich, og Lutherbibelen. Af den sidste forelå en oversættelse af NT til tysk i 1522 — vist den første oversættelse af hele NT til et nationalsprog - mens GT udkom som enkeltdele i løbet af den følgende halve snes år, således at Luthers første helbibel forelå i 1534; han reviderede sin oversættelse nogle gange, og i dansk sammenhæng bør man hæfte sig ved udgaven fra 1545, fordi den danner basis for Christian III's Bibel.

Man skal imidlertid begynde længere tilbage for at finde begyndelsen til den danske bibeloversættelses historie. Rundt om i klostrene fandtes der bibeldele på dansk; f.eks. findes der en ufuldstændig oversættelse af GT så tidligt som fra 1470'erne. Den følger slavisk den latinske tekst, Vulgata, men af sproget skulle man iøvrigt kunne se, at den munk, der har oversat, var af jysk oprindelse.

Men den aførende inspiration til at få oversat Bibelen til et godt dansk kom naturligvis med Reformationen. En milepæl i den sammenhæng er Christiern Pedersens oversættelse af NT (1529). En af de kendteste personer i dansk reformationshistorie, Hans Tausen, besørgede en dansk oversættelse af den hebraiske grundtekst til de fem Mosebøger; den 
udkom i 1533 i et udstyr, der mere end antyder, at det havde været Tausens plan at få hele GT oversat til dansk, men den del af planen blev aldrig ført ud i livet.

I 1550 kom så den første hele Bibel på dansk, den såkaldte Christian III's Bibel. Det blev ikke en oversættelse af grundteksterne, men en fordanskning af Lutherbibelen, som kom til at fungere som den første officielle danske Bibel. Den blev revideret et par gange, sidste gang i 1633, og udkom da som Christian IV's Bibel. Den er særlig interessant derved, at teksten nu blev forsynet med et større kommentarapparat; f.eks. blev en kendt tysk lutheraner, Veit Dietrichs, summarier oversat og brugt som indledning til de enkelte kapitler. Man ønskede at fastholde og videregive den ny kirkelige, d.v.s. lutherske, tradition for, hvordan Bibelen rettelig skulle forstås. Traditionen fra summarierne er bevaret i den nuværende bibeloversættelse i form af de korte kapiteloverskrifter.

I det lange løb syntes det dog utilfredsstillende, at de danske bibeltekster ikke byggede direkte på grundsprogene; der var for mange germanismer. Og allerede før Christian IV's Bibel udkom, havde en lærd mand ved navn Resen udgivet en ny oversættelse (1607), men den led af en anden svaghed, nemlig at den var så ordret, at den ikke kunne bruges i kirken. Den måtte revideres, og det skete i en udgave formidlet af biskop Svane (1647), den resen-svanningske oversattelse. Den holdt sig i virkeligheden helt ind i vort århundrede, men blev selvfølgelig revideret nogle gange undervejs. Men er der noget man tør kalde dansk bibeltradition, guldalderbibelen, så er det den. Det er f.eks. den bibeltradition, som både Kingo, Brorson, Ingemann og Grundtvig har været fortrolige med, da de digtede deres salmer, og, i parentes bemærket, udgør det i virkeligheden et stort problem, når man skal nyoversætte Bibelen, at disse kendte salmedigtere har gjort vendinger fra denne udgave udødelige gennem deres salmer.

En af de revisioner af den resen-svanningske oversættelse, der specielt skal nævnes, er Christian VI's Bibel (1740). Det er sidste gang, der er autoriseret en revision eller nyoversættelse af hele Bibelen på dansk, altså både GT og NT på én gang. På et tidspunkt var det planen, at "vores" hele bibeloversættelse skulle blive færdig til autorisation i 1990, altså i 250-året for Christian VI’s Bibel; men det nås ikke.

Den sidste i rækken af revisioner er fra 1871 for GT's vedkommende og fra 1907 for NT. Man ikke skal mere end treds år tilbage for at støde på den klassiske tradition for hele Bibelens vedkommende, og NT hørte med indtil lige efter anden Verdenskrig. Den Bibel, der i dag er den offi- 
cielle, autoriserede udgave, er sammensat af en ny oversættelse af GT, udgivet i 1931, og af NT, udgivet i 1948. Det bliver således — heldigvis — ikke os, der foretager det første brud med guldalderbibelen.

Inden jeg går videre skylder jeg at nævne et par ting mere, der viser, hvor kompleks den tradition er, som vi står i som bibeloversættere. Lige siden oplysningstiden, altså de sidste godt to hundrede år, har der her i Nordeuropa været tradition for, at der udover de autoriserede bibeloversættelser, er blevet udgivet såkaldte private bibeloversættelser. F.eks. lavede Ove Hфegh-Guldberg, efter at han var styrtet som Gehejmekabinetssekretær i 1784 og var blevet stiftsamtmand her i Århus, sin egen NT-oversættelse (1794). I forrige århundrede udkom der to vægtige oversættelser af hele Bibelen, befordret af to kendte teologer, J.Chr.Lindberg og Chr.H.Kalkar.

I dette århundrede er der udkommet en privat GT-oversættelse, redigeret af professor i semitisk filologi, F.Buhl, internationalt kendt for at have bearbejdet og nyudgivet en af de vigtigste håndbøger for alverdens hebraiskstuderende, W.Gesenius, Hebräisches und chaldäisches (aramäisches) Handwörterbuch über Das Alte Testament. Buhls oversættelse (1910) er strengt videnskabelig; den egner sig ikke til oplæsning og kunne altså ikke bruges i kirken. Men den afslørede, at der var behov for en afløser for efterkommeren af den resen-svanningske oversættelse. Det videnskabelige grundlag var lagt for den autoriserede udgave fra 1931, men sprogdragten heri blev ændret i retning af den traditionelt kirkelige og krydret med en tydelig hang til gammeldags udtryksform, især i poesien.

Som sagt er den sidste udgave af Det ny Testamente autoriseret i 1948; siden da er der udkommet endnu en ny, privat oversættelse af Det ny Testamente, lavet af ægteparret Paul og Anna Sophie Seidelin (1974). Denne oversættelse har været en bestseller og er meget populær i vide kredse; der er næppe nogen tvivl om, at den har været med til at bane vejen for ønsket om en nyoversættelse af hele Bibelen.

Jeg har i de sidste afsnit skelnet mellem autoriserede og private bibeloversættelser. Den sprogbrug hænger sammen med, at med hensyn til brugen af bibeloversættelser i Den danske Folkekirke, er der endnu en lille rest af enevælden tilbage. Når målet med den oversættelse, som jeg er involveret i, er, at det skal blive til en oversættelse til kirkebrug, betyder det, at dronningen i sidste ende skal "autorisere" den, selvfølgelig efter indstilling fra biskopperne og gennem den siddende kirkeminister. 
Men nu til dags kan det ikke ske uden videre. Det demokratiske system kræver sit; der skal være tid til en offentlig debat om oversættelsen inden en bibeludgave autoriseres. Derfor er der udsendt "prøveoversættelser" først. Det Nye Testamente i ny oversattelse udkom i november 1989, mens GT er publiceret som en serie bøger med fællestitlen Det gamle Testamente $i$ ny oversattelse, Davids salmer (1977), Jesaja (1982), Da Gud skabte (1. Mosebog 1 til 2. Mosebog 15) og Tolvprofetbogen (1985), Hezekiels Bog (1986), Jeremjas Bog (1987), Jobs Bog, Ordsprogenes Bog, Daniels Bog og Ruts Bog, Hфjsangen, Pradikerens Bog, Klagesangene, Esters Bog (1989). Resten af GT, d.v.s lovstoffet og de historiske bøger er udgivet i manuskript i fire hæfter (1985-89), som kan købes direkte hos Det danske Bibelselskab.

Det er en god ting, at Bibelen først er udkommet som prøveoversættelse. Der har været ting, der skulle prøves, før der kunne tages endelig stilling. Der er formuleringer, der ikke fandt deres endelige form med det samme; der er ting, som kommissionen har taget beslutning om på et sent tidspunkt, og det må indarbejdes i oversættelsen hele vejen igennem. Endelig er der, naturligvis, ting, der er teologisk og kirkelig uenighed om. Debatten herom må have sin tid. Derfor er vi ikke blevet færdige med oversættelsen til Christian VI's Bibels jubilæum i august 1990; men vi forventer, at arbejdet er helt afsluttet i løbet af efteråret 1991.

\section{Kirkesprog og folkesprog.}

Det er målet at udgive en bibeloversættelse på et gedigent nutidsdansk, som ikke skal være for svulstigt, og som ikke skal bevare ord, der iøvrigt er døde i det danske sprog. Men ligeså lidt, som det var været en opgave at fungere som sprogbevarende, har vi villet være sprogskabende; vi har kun brugt ganske få ordsammensætninger, som ikke har været registreret af Dansk Sprognævn før. Et eksempel er, at vi i en tekst, Ezekiel 31, om et cedertræ med mange ord for krone, grene og kviste skabte og valgte ordet nålehang i analogi med løvhang.

På den anden side har vi undgået slangudtryk, og hvor vi har været opmærksomme på det, har vi undgået sproglige døgnfluer. Men på det område føler man sig aldrig helt sikker. Ord og vendinger, der i dag føles helt neturale, kan på et senere tidspunkt virke komiske og vække forkerte associationer. Det er umuligt at afgøre, hvad der er nutidsdansk og umiddelbart forståeligt en generation frem. I oversættelsen fra 1931 står der i Esajas (Es) 2,11 iøvrigt som i 1871-udgaven: "Herren (skal) alene være høj på hin dag". Det kan man ikke sige længere, og da ordet hin ikke bruges mere, foreslås i PO: "alene Herren er ophøjet på den dag". 
Man kan selvfølgelig ikke lave en bibeloversættelse uden at bruge låneord, men det har været en hovedregel, at der ikke skulle anvendes ord, der stadig føles som fremmedord. Men det er en vanskelig regel at håndtere; der er en grå sone af ord af fremmed oprindelse, som den ene oversætter mener har fået hjemstedsret i dansk, mens en anden stadig fornemmer dem som fremmedelementer. Er f.eks. ordet barbere blevet tilstrækkeligt dansk til at høre hjemme i en bibeloversættelse; skulle man måske hellere vælge det gamle ord rage? I hvert tilfælde kan man næppe erstatte en ragekniv med en barbermaskine (jvf. Es 7,20).

Et af de virkeligt store problemer har været at skabe en tekst, der er umisforståelig, ikke mindst når den høres læst op. Man kan ikke klare sig med, som et sted i Den danske Salmebog (DDS), hvor der står Guds "kærlighed gør næsten godt" (nr.436, v.4), at gå ud over reglerne for gældende dansk retskrivning og skrive Næsten; den finesse høres ikke. Der har været utallige af den slags problemer undervejs, og til tider har vi næsten stået i stampe, p.gr.a. denne problematik. Lad mig blot nævne et enkelt eksempel, hvor vi af hensyn til forståeligheden måtte gøre en tekst mindre poetisk ved at indføje et par ord: "Han nedtramper fyrster som var de ler" (Es 41,25).

Jeg skal ikke her gå ind på det problem, at der i en række dagligdags vendinger indgår skjulte bibelcitater, ofte i former, der ikke længere kan findes direkte i moderne bibeludgaver; det er ikke et nyt problem. Derimod er der grund til at nævne det konserverende element, der ligger i, at det liturgiske sprog og bibelsproget hænger uløseligt sammen. Der har ikke været $\emptyset$ nsker om at fremme en forfladigende udvikling, svarende til at man erstattede den gudstjenestelige hilsen "Herren være med jer" med noget i retning af: "God dag, kan vi starte nu". Det har vel været den oprindelige mening med hilsenen, men der er en mellemliggende historie og brug, der gør, at man ikke skal være for hurtig til at ændre.

Der er tekster man må ændre så lidt som muligt; det gælder ikke mindst Fadervor (Matthæus (Mat) 6,9-13) og Den aronitiske velsignelse (4. Mosebog 6,24-26). I bønnen må man naturligvis ud fra ønsket om at oversætte til nutidsdansk tage fat på sætningen "Helliget vorde dit navn". Forslaget i PO er forsigtigt: "Lad dit navn blive helliget". Det er knapt nutidigt, men det har den fordel, at de følgende led lettere lader sig knytte til: "Lad ... /dit rige komme,/ din vilje ske...". I velsignelsen foreslås først og fremmest, at man ikke længere skelner mellem ansigt og åsyn; der er intet sprogligt grundlag herfor, idet det hebraiske ord er det samme i begge led. 
En kær og elsket tekst som juleevangeliet (Lukas 2), vil man heller ikke kunne forandre radikalt uden at møde mange protester. I de gode gamle dage lød de indledende ord: "Men det begav sig i de Dage, at en Befaling udgik..."; i 1948 blev det til: "Men det skete i de dage, at der udgik en befaling..." og nu forslås i PO: "I de dage udgik der en befaling...". Der er mange, der føler, at den karakteristiske indledning er genrebestemmende på samme måde som eventyret indledes med "Der var en gang..." Men det er en illusion; der er simpelthen tale om en semitisme. Den hebraiske indledningsformel, der knytter to episoder sammen i et sammenhængende forløb, er ordret oversat til græsk og derfra til dansk.

Der er steder, der kommer til at lyde anderledes, fordi det danske sprog har ændret sig. Indledningen til Salme (Sl) 2 lød i 1871: "Hvorfor fnyse Hedningerne, og grunde folkene paa Forfængelighed." 1931-oversættelsen ændrede det til: "Hvorfor fnyser hedninger, hvi pønser folkefærd på, hvad fåfængt er” og det er et eksempel på hangen til arkaismer, i dag egentlig vanskeligere at forstå end 1871-oversættelsen. PO er måske ikke så poetisk, men i hvert tilfælde forståelig: "Hvorfor er folkene i oprør og lægger planer, der ikke kan lykkes."

Den hebraiske eufemisme for at have samleje er verbet at kende: "Adam kendte sin hustru Eva og hun blev frugtsommelig" står der i 1.Mosebog 4 (v.1). I PO er dette vers oversat: "Manden lå med sin kone Eva, og hun blev gravid". Vi lægger først mærke til, at der ikke står Adam; man har taget konsekvensen af, at det ikke er et egennavn. Det er der mange, der er kede af, men værre synes det direkte udtryk at være, selv om det egentlig også er en eufemisme; ikke mindst er der mennesker, der er blevet stødt over, at ord som gravid, menstruation og lignende får plads i en bibeloversættelse. Det er ingen overraskelse, at der blandt bibellæsere er stor følsomhed overfor alt, hvad der har med kønslivet at gøre. Men man kan ikke komme uden om, at der er tekster i Bibelen, der udtaler sig i temmelig utvetydige vendinger om kønslivet; man kan blot læse Ezekiel kap.16, hvorfra der kan hentes mange spændende eksempler.

I 1931-oversættelsen af GT bruges ofte ordet miskundhed om Guds holdning til mennesket. Det er et klassisk ord fra det religiøse sprog, men det er ikke længere umiddelbart forståeligt. En oplagt fejl vil være at slutte sig til, at vi har den negative forstavelse mis og en afledning af kende, d.v.s. at "miskundhed" skulle betyde ikke at kendes ved, men det betyder det modsatte. Ifølge Ordbog over Det danske Sprog (Bd. 14, col.156f) afledes det ganske rigtigt af kende, men i den ældre betydning 
tilregne; meningen er altså: det ikke at tilregne noget. På grund af forståelsesvanskeligheden blev "miskundhed" erstattet af barmhjertighed allerede ved revisionen af NT i 1907. I PO af GT har vi valgt synonymer som godhed og trofasthed.

Men, lyder indvendingen, vi har jo stadig f.eks. Ingemanns salme: "Til himlene rækker din miskundhed Gud, din trofasthed når dine skyer" fra 1845 (DDS nr.26). Strofen bygger på et citat fra Sl 36 (v.6), der i den klassiske bibeloversættelse lød: "Herre, din Miskundhed er i Himlene; din Sandhed naaer til Skyerne". I oversættelsen fra 1931 står der "Herre, din miskundhed rækker (tak Ingemann!) til himlen, din trofasthed når til skyerne", og PO har valgt "Herre, din troskab bor i himlen, din trofasthed når til skyerne". Læg iøvrigt mærke til, at fra 1931 gengives det hebraiske flertalsord ved entalsordet himmel. I dag ser vi et større problem i, hvornår det skal med stort, og hvornår det skal med lille; men det kan jo ikke høres, når teksten læses op.

Jeg ville ikke have noget imod at bevare ordet miskundhed, hvis der ikke fandtes andre udtryk for Guds vilje til ikke at tilregne mennesket skyld og synd. Netop ordet synd er bevaret i bibeloversættelsen, selv om det har en anden betydning end i dagligsproget. Dets indhold kan ikke udtrykkes med andre ord. Men et ord, der let lader sig erstatte med et synonym, bør ikke bevares, når det er gledet ud af sproget og iøvrigt er misforståeligt. Det kan ikke være opgaven at bevare et misforståeligt ord i bibeloversættelsen, blot fordi ordet findes i Salmebogen.

Før teksten er blevet trykt som prøveoversættelse, har den gennemløbet en lang proces. Arbejdsgangen har ikke været helt den samme for GTs og NTs vedkommende, men hovedtrækkene er ens. Bibelen er blevet delt op i større eller mindre dele, som en oversætter, evt. to, har været ansvarlige for med henblik på at producere en første oversættelse i overensstemmelse med de nyeste grammatiker og leksika, og evt. med inddragelse af de klassiske oversættelser. Derefter er teksten gået gennem en redaktionel behandling, der bl.a. har revideret den med henblik på konkordantiske problemer.

Herefter fulgte som oftest en gennemgang i en større gruppe af oversættere, og det var ikke mindst her forholdet til føromtalte danske tradition blev diskuteret; men oversættelsen blev også sammenlignet med nyere oversættelser på moderne sprog. Som nævnt er der en oversættelse i gang i Sverige, hvoraf NT udkom i 1981, mens dele af GT er udgivet i separatbind; i Norge udkom der en ny oversættelse i 1978. Endelig har vi naturligvis orienteret os i ordvalget $\mathrm{i}$ de nyeste bibeludgaver på engelsk 
og tysk og tildels fransk, og her har vi især haft glæde af The New English Bible (nu genudgivet som The Revised English Bible), den franske La Bible de Jérusalem, som også findes i engelsk oversættelse, samt på det sidste den tyske fælleskirkelige oversættelse, den såkaldte Einheitsbibel. Desuden har vi f.eks. konsulteret reviderede udgaver af Zürcherbibelen og Lutherbibelen, foruden naturligvis en række moderne videnskabelige oversættelser og kommentarer.

Teksten er gennemlæst af konsulenter, som har set på den i relation til moderne dansk og til den kirkelige, liturgiske tradition. Det betyder, at en repræsentant for Dansk Sprognævn - for største delens vedkommende lektor Allan Karker - har læst hele oversættelsen igennem, og i den gammeltestamentlige del har Ebbe Kløvedal Reich læst med, mens Jørgen Gustava Brandt tilsvarende har læst NT. Endelig har redaktionen herefter gjort de enkelte bibeldele klar til at blive udgivet som omtalte PO.

Det har aldrig været meningen, at PO uden videre skulle autoriseres til kirkebrug. Derfor arbejdes der stadig videre; det skal afgøres, i hvilken udstrækning kritikken skal få indflydelse på tekstens endelig form. Bibelselskabet har inviteret et halvt hundrede lektører, repræsenterende forskellige sider af kirke-, skole- og kulturliv, til at give deres mening til kende, der er anmeldelserne, og endelig er der indgået en række spontane tilkendegivelser om enkeltproblemer vedrørende oversættelsen. Alt dette behandles nu af en revisionsgruppe for hver af de to testamenter. De to grupper reviderer prøveoversættelserne og forelægger et endeligt forslag for en 17 mand stor kommission, sammensat bl.a. ud fra det synspunkt, at forskellige kirkelige opfattelser bør komme til orde ved den endelige fastlæggelse af ordlyden. Resultatet af kommissionens arbejde fremsendes til Bibelselskabet, der til slut beder den siddende kirkeminister om at tage skridt til at få oversættelsen autoriseret.

\section{Tekst og oversættelsesproblemer}

Da Luther i 1500-tallet valgte at gå bag om Vulgatas latinske tradition var sagen oplagt for NTs vedkommende. Selv om Jesus og hans disciple selv havde talt en semitisk dialekt, sandsynligvis aramaisk, var hans ord i evangelierne overleveret på græsk, og det blev naturligvis græsk, der blev udgangspunkt for Luthers NT. Men for GT er forholdet mere kompliceret; der foreligger klassiske tekster på både græsk og hebraisk. Den tidligste kirke havde jo kun GT som hellig skrift, og for de menigheder, som den vestlige kirke nedstammer fra, var den græske tekst grundlaget. Det er den, der er citeret i NT og hos en række kirkefædre. Ifølge traditionerne fandtes der en yderst troværdig oversættelse, kaldet Septua- 
ginta (LXX); den skulle være oversat af 70 (egentlig 72; 6 x 12) lærde jøder, som havde siddet hver for sig, men deres oversættelser faldt lykkeligvis fuldstændig ens ud.

Reformatorerne vidste, at LXX var en oversættelse, og at der lå en hebraisk tekst bag. Luther havde tilgang til en trykt hebraisk tekstudgave fra 1494, og den blev hovedgrundlaget for hans oversættelse af GT, dog således at han fulgte den tekstrækkefølge, der var kendt fra Vulgata, ligesom også LXX fortsat spillede en rolle for oversættelsen. Luthers valg af den hebraiske tekst har været afgørende for luthersk bibeloversættelse lige siden. Det ligger således klart i forlængelse af den lutherske tradition, når det kommende autoriserede GT er en oversættelse fra hebraisk. Forskelle fra Luthers oversættelse kan først og fremmest skyldes, at kendskabet til hebraisk - og semitiske sprog i det hele taget — er vokset $\mathrm{i}$ anseelig grad i de mellemliggende århundreder, og ikke mindst i dette århundrede. Det er også en af grundene til forskelle i forhold til oversættelsen fra 1931.

For en ordens skyld skal jeg nævne, at hvis Luther havde valgt at gå tilbage til LXX, havde vi naturligvis ikke haft et fuldstændigt anderledes GT, end det vi kender. Men der ville have været markante forskelle. De ti bud findes i en anden rækkefølge i LXX, Jeremiasbogen er disponeret på en anden måde og er lidt kortere, Danielsbogen er derimod længere, og vi ville f.eks. have haft historien om Susanne i badet med i Bibelen. De bøger og andre større dele af LXX, som ikke er med i vore autoriserede udgaver, findes i de såkaldte Apokryfiske bøger, som i en del udgaver er trykt mellem GT og NT — seneste oversættelse er autoriseret i 1953. Luther betragtede dem ikke som ligestillede med den $\emptyset$ vrige Bibel, men dog som "gode og nyttige at læse".

Bibelen er en bog, hvortil der ikke findes nogen original. Ikke alene er en stor del af skrifterne redigeret og senere nedskrevet mundtlig forkyndelse, men selv som redigeret bog, findes ikke en "oprindelig" Esajasbog eller et Lukasevangelium, der går tilbage til evangelisten, eller for den sags skyld Paulus' originale breve. Vi er afhængige af tekstoverleveringen med dens styrke og svagheder.

Strengt taget måtte man rekonstruere sin tekst og foretage en række tekstkritiske valg, inden man gik i gang med at oversætte. I praksis oversætter man efter trykte tekstudgaver; men allerede dette giver en forskel i baggrunden for oversættelserne af de to testamenter. NT er oversat efter Nestle-Aland, Novum Testamentum Graece (26.udg.). Det er ikke et optryk af en bestemt tekst, men en tekstkritisk fremstillet udgave, hvor 
eksperter vers for vers har udvalgt, hvad de betragter som den bedste, d.v.s. oprindeligste tekst. Det betyder f.eks. at den tekst, der skal oversættes, altid er forståelig, og der er kun grund til at gøre tekstkritiske bemærkninger, hvis oversætterne har et andet syn på et problem end udgiverne. I forhold til den gammeltestamentlige oversættelse er der derfor relativt få tekstkritiske noter i "Det nye Testamente i ny oversættelse".

Det gamle Testamente er oversat efter Biblia Hebraica Stuttgartensia, hvori der er aftrykt et af de ældste hele hebraiske Bibelmanuskripter, Codex Leningradensis, samt et tekstkritisk apparat. Teksten kan dateres til 1008, men tilhører en tekstfamilie, hvis historie kan føres tilbage til 7.årh.e.Kr. Når man ikke har ældre manuskripter skyldes det den jødiske synagogetradition, at man tog en ny afskrift af de hellige tekster i brug, såsnart de gamle blev slidt, for ikke at komme til at læse teksten forkert; desværre havde man også den skik normalt at makulere de slidte udgaver. Der er dog meget, der tyder på at tekstoverleveringen har været ganske sikker. I dette århundrede har man jo blandt Dødehavsteksterne fundet bl.a. en hel Esajas-tekst, der går tilbage til vor tidsregnings begyndelse, og der er ikke mange væsentlige afvigelser heri fra f.eks. ovennævnte tekstudgaves Esajasbog.

Men selv et godt manuskript fra fortiden er behæftet med fejl og må korrigeres. Et gammelt hovedprincip inden for tekstkritikken er at vælge lectio difficilior; kort sagt, at man ikke bør korrigere en tekst, selv om den er mærkelig eller vanskelig, hvis den på nogen måde er forståelig. Det er et godt princip, der dog må tages med forbehold, fordi den kan føre til absurditeter. Der er ingen tvivl om, at det er forkert - selv om ordene strengt taget er forståelige - når der står i den hebraiske tekst til 2.Krønikebog 22,2, at en konge, der dør som 40 årig, efterlader en yngste søn på 42 år. Sønnen omtales da også som 22-årig et andet sted, og Krønikebogsteksten må korrigeres herefter.

Et område, hvor det er forholdsvis let at afsløre fejl, er navnelister. De findes ofte i flere udgaver i Bibelen, og navnene går i det hele taget igen. Ved sammenligninger finder man ud af, hvilken slags fejl der typisk er opstået. Det er naturligvis ikke overraskende, at bogstaver, der enten i lyd eller skrift ligger tæt på hinanden, er blevet forvekslet. Man kan herefter tillade sig at antage, at noget tilsvarende kan være sket andre steder, men der findes sjældent nogen hebraisk kontrolinstans hertil. I en række tilfælde lader formodningen om en fejl sig imidlertid underbygge af klassiske oversættelser som LXX eller Vulgata — men man må aldrig lukke 
øjnene for den mulighed, at de klassiske oversættere har set samme vanskeligheder, som den moderne læser, og derfor også har prøvet at gøre teksten mere forståelig.

Der findes dog også andre eksempler end navnelister på, at samme tekst findes flere gange i Det gamle Testamente; f.eks. er Sl 14 den samme som Sl 53, Sl 18 findes også i 1.Samuel (Sam) 22, og Es 2,2-4 er lig med Mika 4,1-3, foruden at en lang række beretninger fra Samuels- og Kongebøgerne går igen i Krønikebøgerne (Krøn). Men ingen steder er der tale om fuldstændig identitet. Et ord kan være erstattet med et synonym fra den ene tekst til den anden; et tilfældigt valgt eksempel er, at der anvendes forskellige ord for lig i 1.Sam 31,12 og 1.Krøn 10,12, og det kommer næppe til at fremgå af den nye autoriserede oversættelse. I to korte tekstafsnit om samme sag som 2.Sam 5,1-3 og 1. Krøn 11,1-3 er der en række småforskelle, der ikke alle kommer frem i den danske oversættelse, men man kan f.eks. notere sig, at selv referatet af, hvad Gud har sagt, er en anelse forskelligt i de to udgaver.

Det tekstkritiske arbejde, der går forud for en autoriseret oversættelse, må ske med stor skønsomhed. Det må ikke blive den enkelte oversætters kæpheste, der rides. Hovedprincippet har været at korrigere så lidt som muligt i Codex Leningradensis, selv om det ikke er helt uden problemer at $\mathrm{g} \varnothing \mathrm{re}$ et $\mathrm{i}$ og for sig tilfældigt håndskrift til den danske folkekirkes Bibel; men det er den slags valg man bliver nødt til at tage.

I de fleste tilfælde har forskellene i ellers identiske tekster fået lov til at blive stående; der kan bl.a. argumenteres med, at forskellighederne kan skyldes, at de to tekster om samme sag er overleveret i forskellige kredse med forskellige udtryksformer. Men i andre tilfælde bliver forskellene naturligvis brugt til at korrigere en oplagt fejloverleveret tekst med. Ved analogislutninger har man så også i enkelte tilfælde foretaget "frie" konjekturer, d.v.s. korrigeret en antagelig fejloverleveret tekst, selv om der ikke findes en hebraisk paralleltekst, eller selv om den korrigerede tekst heller ikke kan spores i nogen klassisk oversættelse.

Alt dette er naturligvis vanskeligt, for ikke at sige umuligt, at gennemskue for en læser. To tekster kan som sagt se ens ud i oversættelsen, selv om de er forskellige på hebraisk; andre steder kan forskellen se større ud, end den er i grundteksten, fordi en forskel i konteksten kan medføre, at samme ord må gengives forskelligt $\mathrm{i}$ to ellers næsten ens tekster. For at give læseren et indtryk af problemets omfang er alle bindene $i$ "Det gamle Testamente i ny oversættelse" udstyret med en liste over de steder, hvor den hebraiske konsonanttekst, som er den ældste tekst, er korrigeret. 
Som netop antydet var hebraisk oprindeligt en konsonantskrift, selv om nogle konsonanter tidligt udviklede en vokalfunktion; disse vokalbogstaver markerede dog kun lange vokaler. Imidlertid udviklede jødiske lærde, kaldet massoreterne (af det hebraiske ord for "overlevering"), fra 6.årh.e.Kr. og fremefter systemer, der angiver, hvordan teksten skal læses op, bl.a. hvilke vokaler, der skal læses, og hvor trykket skal lægges. Det system, man i dag finder i de trykte hebraiske bibler stammer fra 10.årh.e.Kr.

Der er imidlertid ingen tvivl om, at massoreterne har søgt at udjævne forskelle i hebraisk ved hjælp af vokalerne; det mærkes f.eks. ikke på den vokaliserede tekst, at der kan være en aldersforskel på mellem et halvt og et helt årtusinde mellem de ældste og de yngste tekster. Desuden er det ikke sjældent, at de markerer, at der skal læses noget andet end konsonantteksten. Et relativt harmløst eksempel er, at i store dele af GT er der ingen forskel på konsonanterne i hankøn og hunkøn af det personlige pronomen i 3. pers.sing.; men massoreterne har konsekvent markeret den forskel i udtalen, som svarer til konsonantteksten i den øvrige del af GT.

Men massoreterne holdt sig ikke blot til grammatiske korrekturer. Der findes også vokaliseringer, der antyder en teologisk eller religionshistorisk korrektion. Konsonantteksten i Es 2,12 betyder, at de, der ofrer, "kommer for at se mit ansigt" (PO). Men ud fra dogmet om, at man ikke kan se Guds ansigt uden at dø, har massoreterne vokaliseret således, at der kan oversættes "stedes for mit ansigt" (1931). Igen kan man diskutere, hvilken tekst, der skal lægges til grund for danskernes Bibel. Den mest eller mindst anstødelige, måske? Hovedprincippet har været at gå tilbage til den ældste tekst. Det må gerne fremgå, at teksten har haft en historie, inden den er nået frem til os.

Men massoreterne har ikke været de første, der har haft problemer med ordlyden i visse dele af Bibelen. Da Job havde mistet sine børn og al sin ejendom, opfordrede hans kone ham til at "velsigne" Gud, men meningen er selvfølgelig "forbande" (Job 2,9). Tekstoverleveringen har imidlertid ikke turdet at tage sammensætningen forbande Gud i sin mund eller pen, selv her, hvor det er i et referat af en kvinde, der ikke vil sin mands bedste. Vi ved ikke, om Jobs bog altid har haft "velsigne" på dette sted, men der findes jødiske traditioner, der viser, at ændringer svarende til at skrive "velsigne" for "forbande" kan have fundet sted på et tidligt tidspunkt. Spørgsmålet er, om man skal oversætte det hebraiske udtryk ordret, selv om det er meningsløst på dansk, eller vi skal oversætte meningen? Indtil 1871 stod der "(vel)signe" i de officielle oversættelser, 
men i 1931 skar man igennem og skrev "forbande". Det samme gør PO, men vi overvejede undervejs, om man kunne sætte velsigne i "gåseøjne", men igen havde vi det problem, at teksten skal kunne høres læst op.

Sidstnævnte eksempel har noget at gøre med den kendsgerning, at vi kender meget lidt klassisk hebraisk udover GT. Vi kender slet ikke det dagligsprog, som har været samtidigt med Bibelens måske lidt højtidelige sprog. Problemet er, at når vi ikke kender dagligsproget, ved vi ikke, hvad der føltes som højtideligt. Når vi ikke ved, hvad David sagde til Batseba, da han ville i seng med hende, kan vi heller ikke vide, om de erotiske metaforer, der bruges i Højsangen og f.eks. i ovennævnte Ezekiel kap. 16 udtrykker et dagligsprog, et vulgært sprog eller et højpoetisk sprog.

Vi ved generelt for lidt om de associationer, det hebraiske billedsprog har vakt. Derfor er det vanskeligt at afgøre, hvornår man skal oversætte ideomatisk, og hvornår det er rigtigere at beholde forlæggets billedsprog. Der er i den lutherske skriftopfattelse en spore til det sidste, og derfor kan der findes eksempler på billeder, der kunne være udskiftet med andre og lettere forståelige udtryk; f.eks. kan man kun se, at "jeres knogler skal spire som græs" i Es 66,14 er et udtryk for glæde, fordi det står parallelt med "jeres hjerter skal glædes". Udtrykket "spærre mund op" i Es 57,4 ville sikkert blive lettere forståeligt, hvis det blev erstattet med "række tunge".

Men andre steder er det direkte forvirrende, hvis man fastholder en ordret oversættelse. Således bliver man desorienteret, når man i Ezra 4,14 læser: "Da vi nu spiser paladsets salt ..." (1931); her foreslår PO: "Da vi er i kongens tjeneste...". Ved begyndelsen af oversættelsesprocessen var vi mere tilbøjelige til at forlade det bibelske billedsprog til fordel for mere kontante udtryk. Vi var bekymrede for, om folk fandt det forvirrende, at det f.eks. var Guds hånd eller Guds fod, der handlede på Guds vegne. Men senere hen i forløbet har vi nok været mindre bekymrede på det punkt, men er tværtimod blevet bekymrede for, om Bibelen mistede lidt af sin egenværdi på den måde. Er det ikke for ferskt at skrive "dine ord", hvis der f.eks. på hebraisk står "din munds ord" (således f.eks. S1 138,4). Disse overvejelser medfører sandsynligvis, at der bliver mere billedsprog i Davids salmer i den nye autoriserede udgave end der findes i PO.

Det er en bibeloversætters drøm at kunne oversætte sådan, at læseren kan se, hvor der bruges samme ord i grundteksten. Men det forbliver naturligvis kun en drøm, fordi de fleste ord har så stort et betydningsfelt, at de må oversættes forskelligt, afhængigt af konteksten. F.eks. bruges en 
række af ordene for menneskelige organer også for følelser og lignende. Således bruges ordet for moderliv om barmhjertighed; det har oversættelserne vist altid kunnet skelne imellem. Hjertet, derimod, har man været tilbøjelig til at oversætte "ordret", også når der udtrykkes en følelse. Problemet ved det er, at man forventer søde følelser, når man på dansk hører ordet "hjerte". Men på hebraisk er hjertet i mindst ligeså høj grad sæde for det, vi tillægger hjernen: fornuften, og for den sags skyld også viljen. Når man altså på hebraisk "taler til hjertet" kan det være "at tale kærligt", men det kan sandelig også være "at tale til fornuft". Derfor har PO også valgt at bevare ordet hjerte på steder, hvor det måske burde omskrives; det gælder f.eks. Es 40,2.

Jeg nævnte før, at massoreternes vokalisering af teksten har tilsløret den sproghistoriske udvikling af hebraisk. Men det udelukker ikke, at man kan spore en udvikling, f.eks. i et ords betydningsfelt, og det kan medføre en konflikt med hensynet til netop at ville markere, at samme hebraiske ord er brugt. Det gælder f.eks. ordet tôra, som jøderne også i dag bruger om Loven. Oprindeligt har det ord betydet "belæring" eller "åbenbaring", og det gjorde det sandsynligvis på profeten Esajas tid. Derfor må tôra oversættes belaring i Esajasbogen; men sandsynligvis stammer en stor del af denne profetbog fra en senere tid, hvor ordet betød lov. Dilemmaet er nu, om man skal lade den indre sammenhæng i Esajasbogen eller den historiske udvikling, som litterære undersøgelser af teksterne har afsløret, være udslagsgivende for oversættelsen. PO har valgt at lade profetbogen som kontekst for ordet være afgørende; tôra er derfor stort set gengivet "belæring" hele bogen igennem.

Der er et problem, som man ikke har været nødt til at tænke igennem siden 1740, fordi nyoversatte eller reviderede udgaver af GT og NT aldrig er udkommet samtidigt i denne periode. Det er, hvordan forholder man sig med de tekster, der i GT bliver oversat fra hebraisk efter én teksttradition og er citeret i NT på græsk efter en anden teksttradition? Som det er fremgået ovenfor, er de to testamenter oversat hver for sig, og derfor er det først her i revisionsfasen, problemet for alvor kommer for en dag. Jeg kan derfor ikke på nuværende tidspunkt sige, hvordan det ender, men man vil sandsynligvis arbejde henimod at få de flest mulige steder til at lyde ens, men hvor det vil kræve for mange kompromiser, må man finde en anden form for genkendelighed end direkte ord-lighed.

Men jeg kan give et eksempel, hvor citat-problematikken ikke er så påtrængende, men hvor genkendeligheden alligevel er et problem. I Bjergprædikenen findes en række sentenser, der næsten udgør en genre for sig, nemlig de såkaldte saligprisninger (Mat 5). I 1948-oversættelsen 
stod der f.eks. "Salige er de fattige i ånden, thi himmeriget er deres". Igen fordi det er kendte og meget brugte ord har PO til NT været forsigtig. Ordet salig er bevaret, men "thi" springes over. I GT har man imidlertid en række udsagn, der begynder med et hebraisk ord, der svarer til det græske ord, der er oversat "salig"; i disse tilfælde er der tradition for også at oversætte "salig" i GT (f.eks. Sl 1,1), men PO foreslår at skifte det ud med lykkelig. Ordet er i GT egentlig det modsatte af "ve den.." Salig betyder ikke det og har i det hele taget ikke længere en klar betydning uden for de egentlige saligprisninger; derfor er det forkert at bevare det, selv om der går en oprindelig sproglig sammenhæng tabt.

Lad mig slutte med et par eksempler på, at der står et helt andet ord i PO, end man er vant til, fordi man har fået et større kendskab til semitisk filologi. De fleste danskere kender Grundtvigs adventssalme "Blomstre som en rosengård" (DDS, nr.60). Det er en gendigtning af Es 35, men går man til den tekst i PO vil man ikke finde nogen "rose", men derimod en "lilje". At finde de rigtige blomsternavne er et stort problem i sig selv, og i dette tilfælde er der mange moderne forslag til, hvad det skal være. Man er blot sikker på, at det ikke er en rose. Det bliver Grundtvigs salme nok ikke ringere af, men man kan ærgre sig over, at man ikke længere kan se sammenhængen.

Mit sidste eksempel har været meget omdiskuteret og er fyldt med teologisk sprængstof. Es 7,14 lød i 1871: "Jomfruen bliver frugtsommelig og føder en Søn, og hun kalder hans Navn Immanuel”, og denne formulering er stort set bevaret i 1931-oversættelsen.

Ordet jomfru er diskutabelt her; det fremgår allerede af en note til oversættelsen fra 1931. Det hebraiske ord er sjældent, men hebraiske og ikke mindst semitiske paralleller, som man ad arkæologisk vej har stiftet bekendtskab med inden for det sidste halve århundrede, tyder på, at det blot bør gengives ung pige eller, da det er en højtidelig sammenhæng, måske ung kvinde. Ordet røber ikke, om hun var gift eller ej. Men hvis hun var gift, var hun næppe jomfru; var hun derimod ugift var hun nok jomfru, ellers havde hun sat sig ud over samfundets regler i en grad, der ville medføre dødsstraf.

Hertil kommer, at ordet "jomfru" ikke længere bruges om en ung pige på dansk, og at det sandsynligvis ikke oprindeligt har haft den specielle betydning, som det har fået; det er jo et tysk låneord, der oprindelig just betyder "ung kvinde". Alt dette taget i betragtning foreslår PO: "den unge kvinde er gravid, hun skal føde en søn og give ham navnet Immanuel" - selv om oversætterne selvfølgelig ved, at det er et sted, der spil- 
ler en central rolle i forbindelse med dogmet om jomfrufødslen. Ordet gravid er nok ikke tilstrækkeligt poetisk her, men resten bør blive som det er.

LXX har opfattet pigen som ugift, og så er der egentlig ikke noget "forkert" i at kalde hende jomfru. Det har LXX også gjort, hvor det drejer sig om andre ugifte kvinder i GT, der ikke udtrykkeligt omtales som jomfruer på hebraisk. Men man har sikkert i dette særlige tilfælde knyttet til ved en kendt ide om et under, hvor en ubesmittet kvinde skulle føde et barn, der skulle komme til at redde verden.

På det afgørende punkt er det LXX's tekst, der er citeret på græsk i NT, i Mat 1,22-23, i forbindelse med Jesu fødsel. I PO er disse vers derfor oversat således: "Alt dette skete, for at det skulle opfyldes, som Herren har talt ved profeten, der siger: Se, jomfruen skal blive med barn og føde en søn, og de skal give ham navnet Immanuel”.

Eksemplet har mange perspektiver; men en ting står klart, at det ikke er oversættelsens problem, om den nytestamentlige brug af forjættelseopfyldelse er rimelig. Man kan også konstatere, at der er andre, men mindre forskelle mellem den hebraiske og den græske tekst. Men det er klart, at det er problematikken jomfru-ung kvinde, der står i fokus i debatten. Med det valg, der er foretaget, er der markeret, at NT her som en række andre steder tolker samtidig med, at det citerer en gammeltestamentlig tekst.

Som sagt bliver dette kontroversielle eksempel mit sidste; alene diskussionen heraf vil medføre, at vi ikke får en autoriseret bibeloversættelse de første mange måneder.

Jeg undlod at tage mit udgangspunkt i teoretiske overvejelser om oversættelsesarbejdet. Jeg håber, at jeg gennem de anførte eksempler har indfriet mit løfte om at angive dem mellem linjerne undervejs på de foregående sider. 


\section{Note}

Kernen i artiklen blev holdt som forelæsning ved Lingvistisk kollokvium på Det erhverssproglige fakultet ved Handelshøjskolen i Århus, tirsdag d.28.11.1989. Artiklens forfatter er dr.theol. og lektor ved Institut for Gammel Testamente, Århus Universitet; han har været med i det gammeltestamentlige oversættelsesarbejde stort set fra begyndelsen og har i særlig grad som oversætter arbejdet med de profetiske skrifter, hvilket ligger i forlængelse af hans øvrige videnskabelige arbejde. Siden 1985 har han været med i redaktionen og sidder nu i revisionskommiteen, samt i den omtalte 17-mands kommission. Sammen med lektor John Strange har han udgivet Skriv synet tydeligt på tavler! (Gad, København 1989). Det er et festskrift til den gammeltestamentlige oversættelses førstemand, professor Svend Holm-Nielsen, og indeholder 16 artikler med tilknytning til oversættelsesproblematikken. 
